\title{
A 1000 year climate ice-core record from the Guliya ice cap, China: its relationship to global climate variability
}

\author{
L. G. Thompson, E. Mosley-Thompson, M. E. Davis, P. N. Lin, J. Dai, J. F. Bolzan, \\ Byrd Polar Research Center. The Ohio State University, 1090 Carmack Road, Columbus, OH 4.3210, U.S.A. \\ T. YAO \\ Lanzhou Institute of Glaciology and Geocryology, Chinese Academy of Sciences, Lanzhou 730000, China
}

\begin{abstract}
In 1992, an American-Chinese expedition successfully recovered three ice cores (308.6, 93.2 and $34.5 \mathrm{~m}$ ) from the Guliya ice cap (summit $6710 \mathrm{~m}$ a.s.l.) in the far western Kunlun on the Qinghai-Tibetan Plateau, China. Guliya resembles a "polar" ice cap with $10 \mathrm{~m}, 200 \mathrm{~m}$ and basal temperatures of $-15.6^{\circ},-5.9^{\circ}$ and $-2.1^{\circ} \mathrm{C}$, respectively. The $308.6 \mathrm{~m}$ core to bedrock is the longest ice core retrieved from an elevation greater than $4000 \mathrm{~m}$ a.s.l. and provides the first ice-core history from the western side of the Qinghai Plateau. The Plateau experiences a pronounced annual precipitation cycle during which $70-80 \%$ of annual total precipitation falls in the summer monsoon season. This leads to a marked visible stratigraphy in the glaciers which allows accurate dating of the ice cores and reconstruction of the net mass accumulation.

This paper presents (1) the results of the geophysical program to determine ice thickness, ice flow and surface topography, (2) an assessment of net accumulation from stake measurements, snow pits and shallow core samples, and (3) the analyses of the upper $100 \mathrm{~m}$ of the $308.6 \mathrm{~m}$ core which provide a 1000 year history, including the "Little Ice Age", which is compared with Chinese historical records. Extended periods of positive accumulation on Guliya are closely contemporaneous with dry periods in eastern China. A trans-Pacific teleconnection is suggested by the strong temporal coherence between extended wet and dry phases on Guliya and on the Quelccaya ice cap, Peru.
\end{abstract}

\section{INTRODUCTION}

Ice sheets and ice caps serve as libraries of atmospheric history from which past climatic and environmental conditions may be extrapolated. Glaciers at high elevations on the Qinghai-Tibetan (Q-T) Plateau cover an area of $\approx 57000 \mathrm{~km}^{2}$ (Shi and Wang, 1981) and, if judiciously selected, may provide a spatially coherent climate history for this region. The Plateau, one of the most imposing topographic features on the Earth's surface, has a mean elevation of $\approx 4.5 \mathrm{~km}$ and comprises an area half that of the U.S.A. The sensible heat flux and the latent heat release over the Q-T Plateau drive the regionally intense monsoon circulation, and strongly influence global circulation patterns. Reliable meteorological observations are limited for much of this extensive region.

The primary ice-core records currently available from this area are from the Dunde ice cap $\left(38^{\circ} 06^{\prime} \mathrm{N}, 96^{\circ} 24^{\prime} \mathrm{E}\right.$; $5325 \mathrm{ma}$ a.s.l.) on the northeastern margin of the Q-T Plateau and the Guliya ice cap $\left(35^{\circ} 17^{\prime} \mathrm{N}, 81^{\circ} 29^{\prime} \mathrm{E}\right.$; $6710 \mathrm{ma}$ a.s.l.) on the far western margin. The proxy climatic histories from both these sites are of high (annual) resolution. The Plateau experiences a marked annual cycle in which $70-80 \%$ of the precipitation falls during the Northern Hemispheric summer producing a distinct visible stratigraphy in the glaciers which allows accurate dating of the ice cores and reconstruction of the net mass accumulation (Thompson and others, 1989, 1993; Thompson, 1992).

The Guliya ice cap is the highest, largest $\left(>200 \mathrm{~km}^{2}\right)$ and thickest $(308.6 \mathrm{~m})$ subtropical ice cap yet investigated. It is part of an ice mass which extends over $8000 \mathrm{~km}^{2}$ in the western Kunlun Mountains. In a cooperative effort, investigators from the Byrd Polar, Research Center (BPRC) of The Ohio State University (OSU), U.S.A., and the Lanzhou Institute of Glaciology and Geocryology (LIGG), China, undertook a 3 year field and laboratory program (1990 92) to study this very high-elevation ice cap. During the 1990 and 1991 field seasons, surface, snow-pit and shallow core samples were recovered. In the summer of 1992, the cooperative BPRC-LIGG expedition successfully recovered three ice cores, 34.5, 93.2 and $308.6 \mathrm{~m}$ in length. Annual accumulation is quite variable ranging from 140 to $260 \mathrm{~mm}$ w.e. among sites. The combination of relatively high (though variable) accumulation, $10 \mathrm{~m}$ borehole temperatures of $-15.2^{\circ}$ to $-17.7^{\circ} \mathrm{C}$ and the distinct monsoonal climate produces the marked annual stratigraphy which is necessary to extract a high-quality icecore record of climatic and environmental variability. 
This paper presents the most recent 1000 years of this icecore-derived history.

\section{FIELD AND LABORATORY METHODS}

Table 1 presents the entire suite of cores drilled and pits sampled from 1990 to 1992 . The 1990 expedition took place from September to October, after the monsoon season; the 1991 field program in May, prior to the onset of the monsoons; and the 1992 field program from July to August, during the primary accumulation season. Each year, pits were excavated and sampled for dust, $\delta^{18} \mathrm{O}$ and chemical analyses at the different drill sites. Each year, ice thicknesses were measured with short-pulse radar at various locations around the ice cap. Ice thicknesses range from $103 \mathrm{~m}$ at the summit, to $200 \mathrm{~m}$ at site 1 , to $310 \mathrm{~m}$ at site 2 . Based upon the thicknesses and the results from the pit samples, sites 1 and 2 were chosen for drilling to bedrock.

At site 1 (Fig. 1) an electromechanical drill was used in an air-filled hole to recover a core to $93.2 \mathrm{~m}$ where drilling was aborted because an unconformity in the ice layers was observed at $83 \mathrm{~m}$. This core was cut into 1783 samples in the field which were melted and put in bottles sealed with wax to prevent vapor transfer and preserve the isotopic record. At site 2 the electromechanical drill was used in a dry hole to $200 \mathrm{~m}$, and from $200 \mathrm{~m}$ to bedrock $(308.6 \mathrm{~m})$ a thermal drill was used with an alcohol/water mixture to ensure better core quality. No hiatus was observed in core 2, and the visible layers remained horizontal throughout. The entire core was returned frozen to the cold rooms at BPRC-OSU.

The visible stratigraphy of the cores was recorded in the field, and air-bubble characteristics and crystal sizes were determined at various intervals along core 2 . All icecore, surface and pit samples were analyzed for microparticle concentrations (MPC), oxygen-isotopic ratios $\left(\delta^{18} \mathrm{O}\right)$ and selected chemical species $\mathrm{Cl}^{-}, \mathrm{NO}_{3}{ }^{-}$and $\mathrm{SO}_{4}{ }^{2}$. Core 2 was cut into 4300 samples for MPC and $\delta^{18} \mathrm{O}$ and 3200 samples for chemical analyses. MPC was measured using two Coulter counters (Model TAII) equipped with 30 and $100 \mu \mathrm{m}$ aperture tubes which provide particle concentrations in sizes ranging in diameter from 0.63 to $40 \mu \mathrm{m}$. The concentrations of specific chemical species were determined using a Dionex Model 2010i ion chromatograph (see Dai and others (1995) for methodological discussion). All samples (except $\delta^{18} \mathrm{O}$ ) were analyzed in a class-100 clean room at BPRC, and $\delta^{18} \mathrm{O}$ was measured with a Finnegan Mat

Table 1. Spatial and temporal sampling on the Guliya ice cap. P, pit; SC, shallow core; DC, deep core; b, bollled; $i$, ice. Refer to Figure 1 for site locations. Elevations were determined using GPS

\begin{tabular}{lcccc}
\hline Sile & Elevation & \multicolumn{3}{c}{ Nature of samples } \\
& \multicolumn{1}{c}{ Fall } & Spring & Summer \\
& $\mathrm{m}$ & 1990 & 1991 & 1992 \\
\hline 1 & 6040 & $\mathrm{P}(\mathrm{b}) \quad \mathrm{SC}(\mathrm{b})$ & $\mathrm{SC}(\mathrm{i})$ & $\mathrm{DC}(\mathrm{b})$ \\
2 & 6200 & $\mathrm{SC}(\mathrm{i})$ & $\mathrm{P}(\mathrm{i}) \quad \mathrm{DC}(\mathrm{i})$ \\
3 & 6200 & & $\mathrm{SC}(\mathrm{b})$ & \\
Summit & 6710 & $\mathrm{SC}(\mathrm{i})$ & $\mathrm{P}(\mathrm{b}) \quad \mathrm{SC}(\mathrm{b})$ & \\
& & & &
\end{tabular}

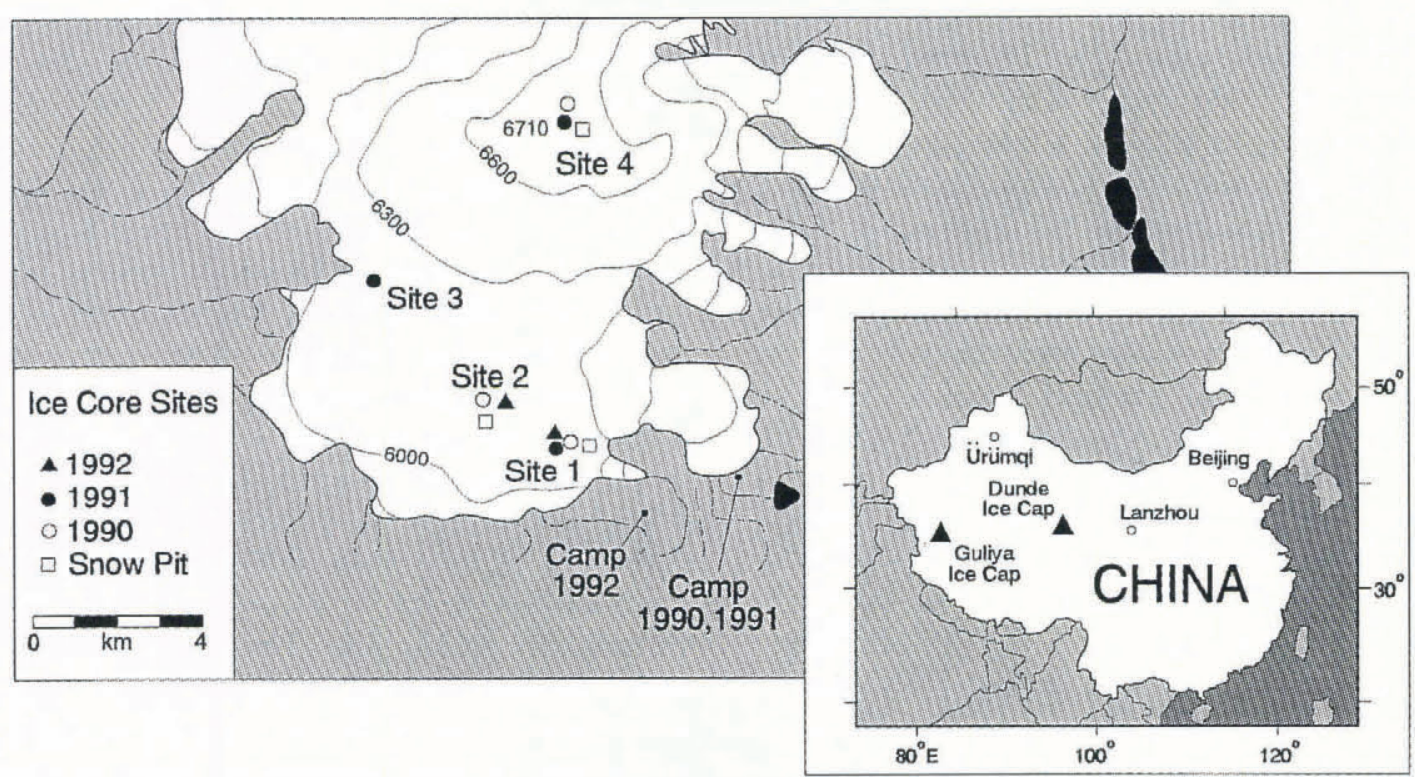

Fig. 1. Locations of the Guliya and Dunde ice caps, and of snow-pit and ice-coring sites on Guliya. 
Delta-E mass spectrometer. Finally, the upper $20 \mathrm{~m}$ of the $34.5 \mathrm{~m}$ core drilled at site 2 were analyzed with high temporal resolution for solid particulate beta radioactivity $(\beta)$ and tritium to locate in the core the massive 1962 Soviet Arctic atmospheric thermonuclear tests. The depth of this known time-stratigraphic horizon is useful for time-scale calibration.

\section{GEOPHYSICAL STUDIES}

The pole displacement in the Guliya strain net was measured in June 1991 and again in July 1992. The velocity vectors (Fig. 2a) reveal that the core 2 site, located over a topographic bedrock depression (Fig. 2b), experiences active ice flow toward the south-southeast at an average speed of $4.8 \mathrm{~m} \mathrm{a}^{-1}$. The core 1 site (Fig. 2c), located near the margin of the ice cap, sits on a topographically smooth bedrock dome and exhibits little horizontal ice flow (Fig. 2a). Short-pulse radar data provided the thicknesses shown along the $\mathrm{A}-\mathrm{B}$ transect (Fig. 2b) containing the core 2 site, and along the C-D transect (Fig. 2c) connecting the core 2 and core 1 sites.

Thermistors were used to measure borehole temperatures at each drill site (Fig. 3). $10 \mathrm{~m}$ temperatures range from $-15.2^{\circ}$ and $-15.6^{\circ} \mathrm{C}$ at sites 1 and 2 , respectively, to $-17.4^{\circ} \mathrm{C}$ at the 1991 summit shallow drill site. At site 2, temperatures ranged from $-15.6^{\circ} \mathrm{C}$ at $10 \mathrm{~m}$ to $-5.6^{\circ} \mathrm{C}$ at $200 \mathrm{~m}$, the depth where dry-hole drilling was suspended and fluid was added to the borehole. A basal temperature of $-2.1^{\circ} \mathrm{C}$ was recorded four days after the completion of drilling and thus may not be representative of the equilibrium temperature due to the presence of the fluid. Nevertheless, the profile for the core 2 borehole demonstrates that the Guliya ice cap thermally resembles a "polar" ice cap.

\section{DISGUSSION}

The major drill sites on the Guliya ice cap are located near the 400 mbar level in the Earth's atmosphere where highlevel plateau and mountain processes are neither well documented nor understood. The firn-to-ice transition at sites 1 and 2 lies within the upper meter of the ice cap. This observation was unexpected given the higher elevation and lower temperatures on Guliya compared to those encountered on other glaciers in the Q-T Plateau region. For example, the Dunde ice cap, which is lower in elevation $(5325 \mathrm{~m})$ and warmer $\left(-7.1^{\circ} \mathrm{C}\right.$ at $\left.10 \mathrm{~m}\right)$, has a firn-to-ice transition at $30 \mathrm{~m}$. Even the Gregoriev ice cap in the Tien Shan $\left(42^{\circ} \mathrm{N}, 78^{\circ} \mathrm{E} ; 4660 \mathrm{~m}\right.$ a.s.l. $)$, to the north, is warmer than the Dunde ice cap, but it contains a firnto-ice transition at $22 \mathrm{~m}$ (Thompson and others, 1993).

The annual accumulation $\left(A_{\mathrm{n}}\right)$ varies across the Guliya ice cap. Accumulation was measured by three methods: (1) accumulation stakes, (2) visible stratigraphy in pits, and (3) insoluble particulate $\beta$ and tritium horizons. Measurements from accumulation poles vary from $650 \mathrm{~mm} \mathrm{a}^{-1}$ of snow $(256 \mathrm{~mm}$ w.e.) at the summit to 380 and $320 \mathrm{~mm} \mathrm{a}^{-1}$ (169 and $143 \mathrm{~mm}$ w.e.) at sites 1 and 2 , respectively. These values are consistent with stake results (Ageta and others, 1989) from 1985 to 1987 on the

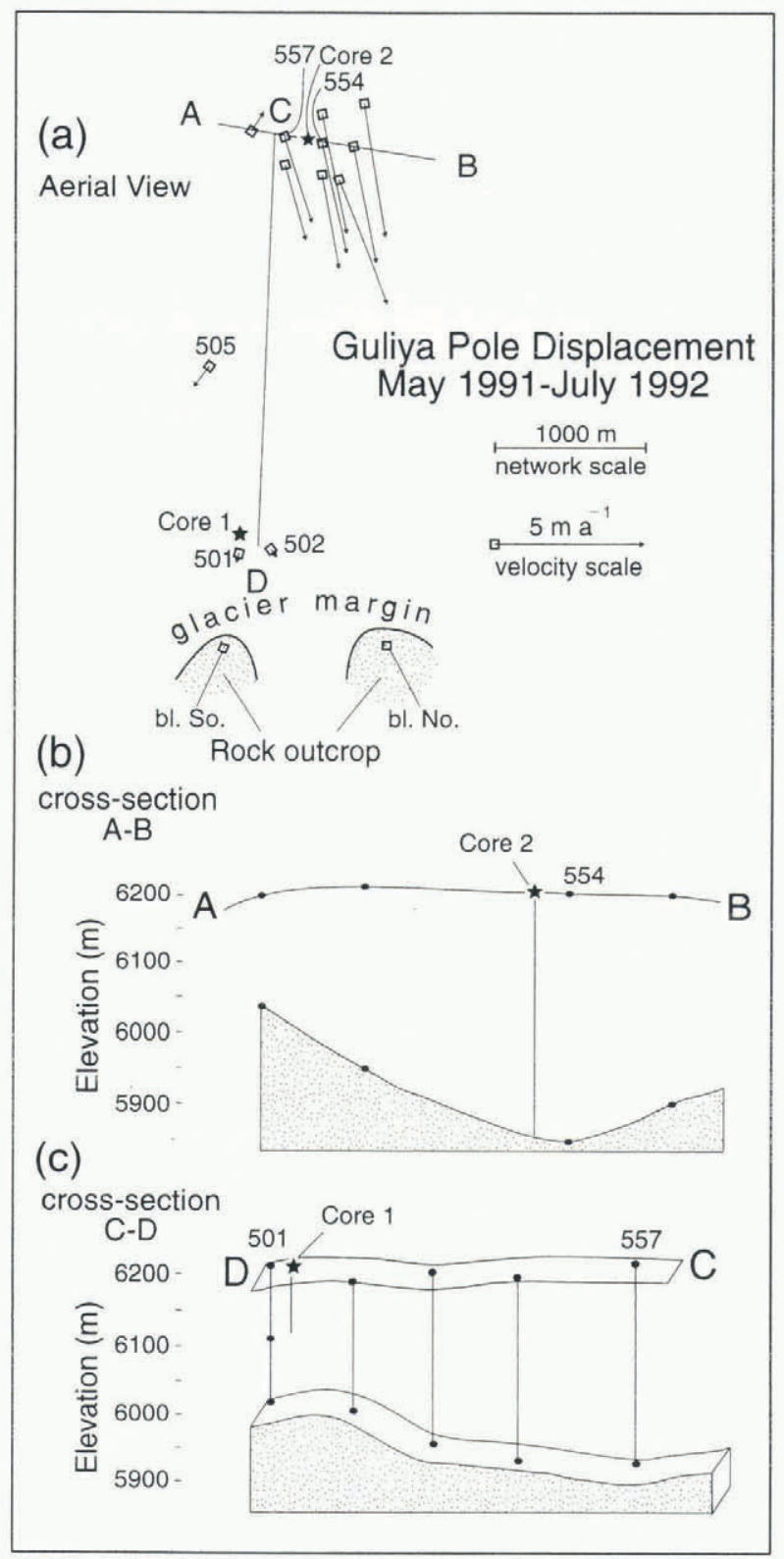

Fig. 2. (a) Aerial view of pole displacements from May 1991 to July 1992 for the core 1 and core 2 drill siles. Displacements were determined relative to bedrock base lines: south point (bl. So.) and north point (bl. No.). The ice-thickness profiles were measured during a shortpulse radar survey along $(b)$ transect $A-B$ through the core 2 drill sile and along (c) transed C - D from the core 2 drill site to the core 1 drill site.

Chongce ice cap, $30 \mathrm{~km}$ west of Guliya. Here accumulation ranges from $150 \mathrm{~mm}$ w.e. at $6000 \mathrm{~m}$ to $300 \mathrm{~mm}$ w.e. at the Chongce summit $6200 \mathrm{~m})$.

A pit was excavated in 1992 adjacent to the accumulation pole at site 2 where the $308.6 \mathrm{~m}$ core was drilled. The visible dust layer between 0.55 and $0.70 \mathrm{~m}$, coupled with the analyses of MPC, $\delta^{18} \mathrm{O}$, and chemical species (Fig. 4), indicate a 1991/92 layer thickness of $\approx 500 \mathrm{~mm}$ of snow or $220 \mathrm{~mm}$ w.e. Figure 5 illustrates the insoluble particulate $\beta$ and tritium profiles from a $34.5 \mathrm{~m}$ core drilled at site 2 in 1992. The highest activity occurs at $5.5 \mathrm{~m}$, and likely corresponds to the massive Soviet Arctic atmospheric thermonuclear testing of $1962 / 63$. If correct, this indicates that $A_{\mathrm{u}}$ at site 2 was $180 \mathrm{~mm}$ w.e. 
Temperature Profile $\left({ }^{\circ} \mathrm{C}\right)$ Guliya Ice Cap, China

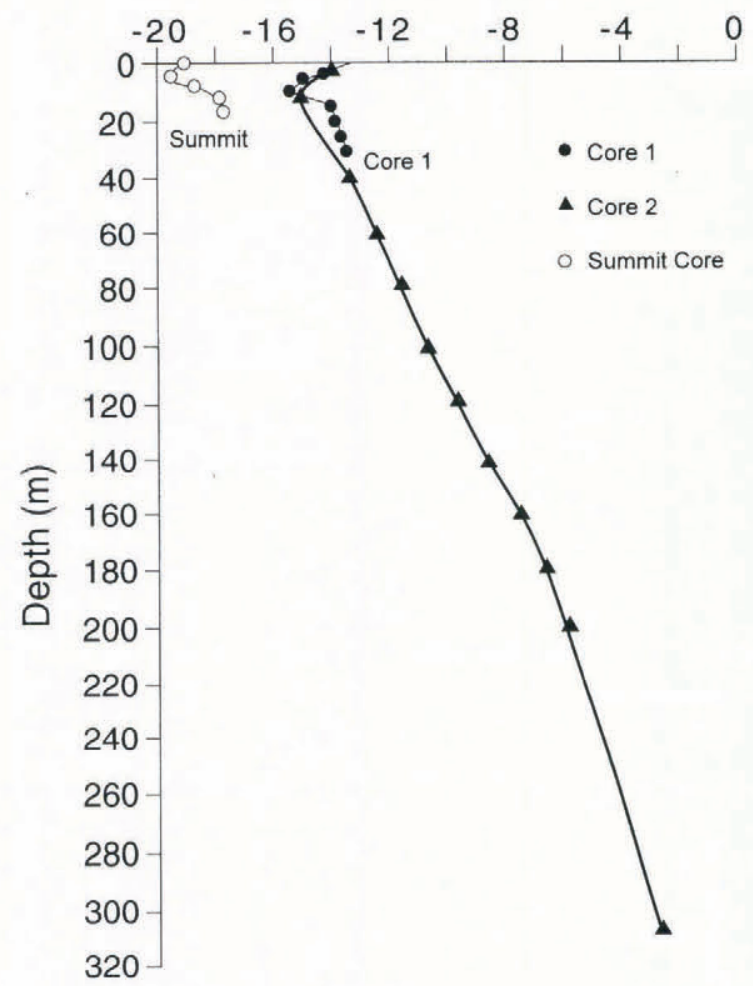

Fig. 3. Vertical temperalure profiles measured in three boreholes using a four-point calibration thermistor string. Temperatures in the $308.6 \mathrm{~m}$ hole range from $-15.6^{\circ} \mathrm{C}$ at $10 \mathrm{~m}$ to $-2.1^{\circ} \mathrm{C}$ at the ice/bedrock contact. These data illustrate that Guliya is a "polar" ice cap.

from 1963 to 1992 . The single-year value $(220 \mathrm{~mm}$ w.e.) from the pit at site 2 is consistent with the longer-term average determined from the beta radioactivity profile for the last 29 years.

\section{YEAR GULIYA ICE-CORE HISTORY}

Based on the pit and surface studies discussed above, the visible layers appear to be annual and may be used to date the core and extract annual layer thicknesses for the

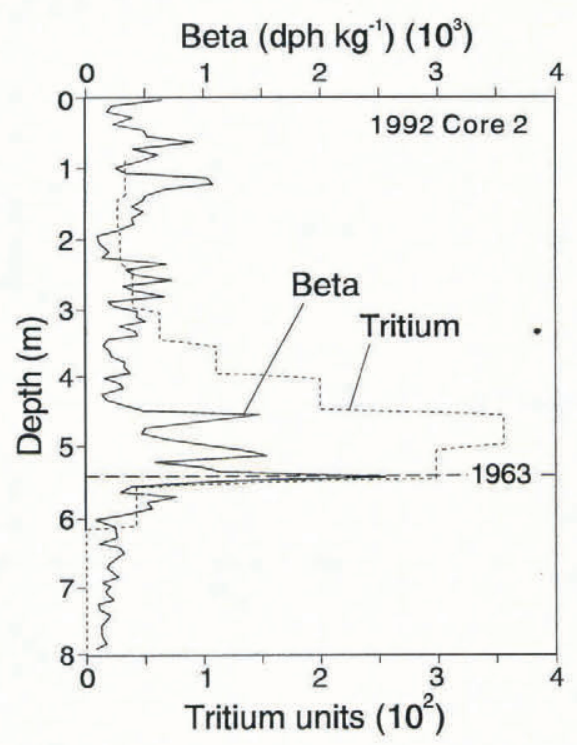

Fig. 5. The total beta-radioactivity and tritium profiles from the core 2 site clearly reveal the prominent 1963 marker horizon.

last 8000 years. This paper discusses only the most recent 1000 years.

The visible annual dust layers were used to reconstruct the net accumulation for the past 1000 years. Although layer thicknesses can be measured throughout both cores (Fig. 6), they do not directly represent the thickness of the originally deposited layer. The original layer is thinned and stretched as new snow accumulates and as the ice flows outward; therefore, the thinning of each layer must be estimated. This was done using a simple flow model discussed by Thompson and others (1985, 1989). The reconstructions presented here are particularly robust as the upper $100 \mathrm{~m}$ of the core comprise only one-third of the total ice thickness. Thus, this part of the core sits well above the bed and should be free of problems associated with basal topography and potentially contorted flow at depth.

This proxy reconstruction provides the first glimpse of the history of $A_{\mathrm{n}}$ at high elevations in far western China. The $A_{\mathrm{n}}$ records from Guliya and Dunde are compared (Fig. 7) with the historical wetness/dryness index for the eastern half of China (Zhang, 1981) since $1500 \mathrm{AD}$. The low-frequency trends which are fairly consistent between

Guliya Ice Cap, China: 1992 Pit 2

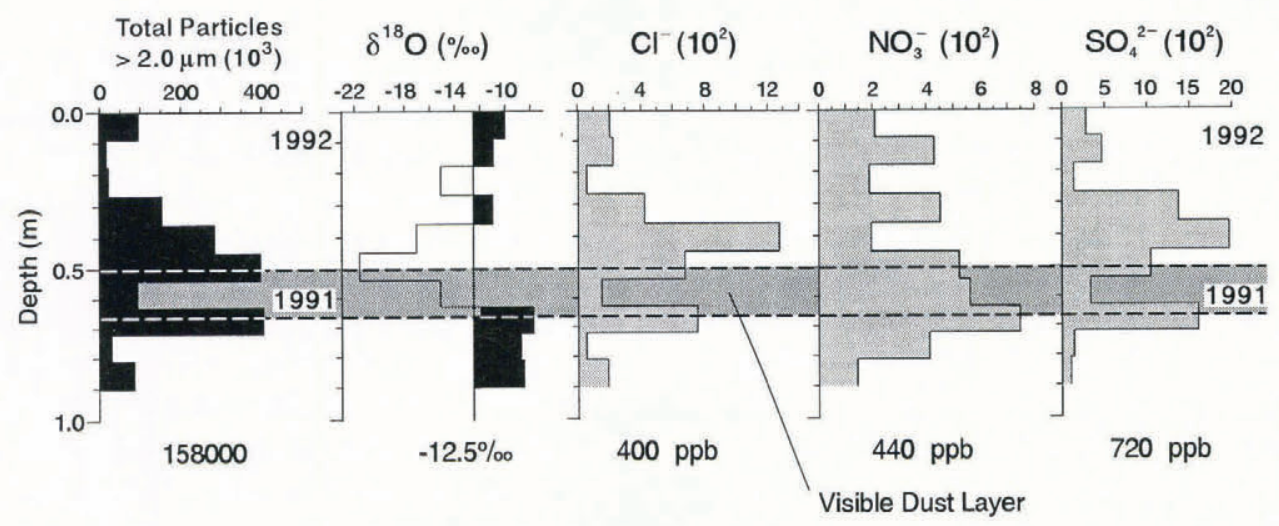

Fig. 4. The analyses of snow-pit samples collected in 1992 at the core 2 site, along with a major dust layer from 0.55 to $0.70 \mathrm{~m}$, indicating a 1991/92 layer thickness of $\approx 500 \mathrm{~mm}$ of snow, or $220 \mathrm{~mm}$ w.e. Averages for each profile are shown. 


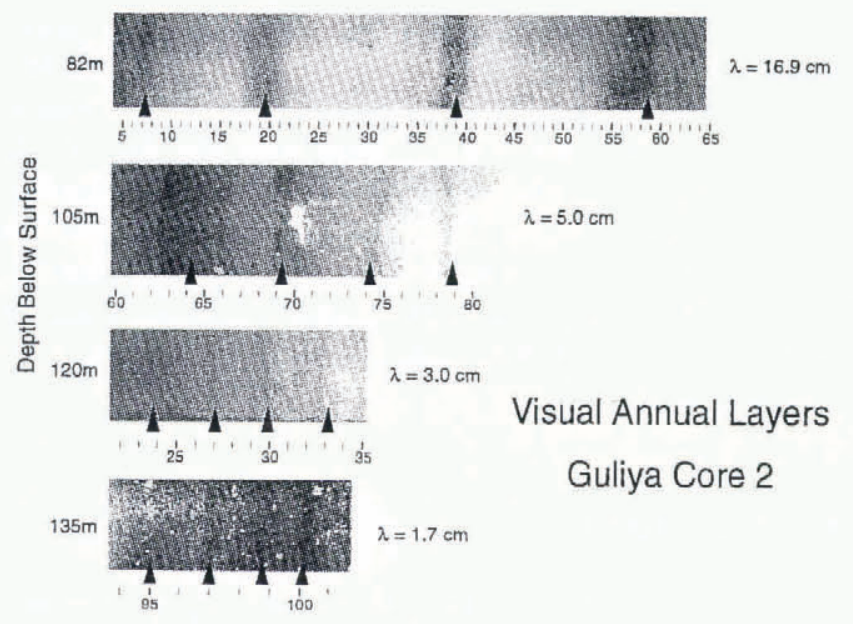

Fig. 6. Four representative core sections of Guliya core 2 show the distinct dry-season dust layers (triangles) used for dating. Average thicknesses $(\lambda)$ of these annual layers are shown as is the layer thinning with depth.

the two ice-core records are out of phase with those in the lower elevations of eastern China. Generally wetter conditions on the Q-T Plateau from 1500 to $1700 \mathrm{AD}$ and during the 20th century are contemporaneous with drier conditions in eastern China (Domrös and Gongbing, 1988; Wang and Zhang, 1992), suggesting an anti-phase relationship in the lower frequencies of the precipitation histories between the high Q-T Plateau and the eastern lowlands of China. Analyses of rainfall patterns during the 17th century (Zhang and Crowley, 1989) indicate that dry conditions were prevalent primarily in northern and western China. They suggest that this pattern might reflect suppression of summer monsoon development, possibly as a result of expanded Eurasian snow cover (Dey and others, 1985; Barnett and others, 1988). The southeast and southwest monsoon systems are linked, but not in a simple way (Ramage, 1971, p. 186, 238; Barry and Chorley, 1992, p. 247).

The 1000 year $A_{\mathrm{n}}$ history reconstructed from annual layer thicknesses in the upper $100 \mathrm{~m}$ of Guliya core 2 is compared in Figure 8 with the only other comparable high-resolution, non-polar $A_{11}$ record, that from Quelccaya ice cap in the southern Andes of Peru (Thompson and others, 1985, 1986, 1988). The Guliya record reveals high-frequency $A_{\mathrm{n}}$ oscillations superimposed upon lowerfrequency $A_{n}$ oscillations corresponding to three extended wet periods (1000-1075 AD, $1400-1775 \mathrm{AD}$ and 1900 present) and two extended dry periods (1075-1375 and 1775-1900 AD). The similarity between these $A_{\mathrm{n}}$ histories is striking (Fig. 8), as the sites are $20000 \mathrm{~km}$ apart on opposite sides of the Pacific basin. During the last 1000 years major periods of drought and wetness appear to have been contemporaneous in the southern Andes and on the Tibetan Plateau suggesting a teleconnection between these regions. In fact, meteorological observations for the last 100 years reveal a well-established teleconnection for higher-frequency climate events such as the El Niño Southern Oscillation ENSO) Namais, 1963; Rasmusson and Carpenter, 1983; Barnett and others, 1988). Now, for the first time, longer temporal perspectives available from ice-core records suggest that lower-frequency teleconnections may exist as well.
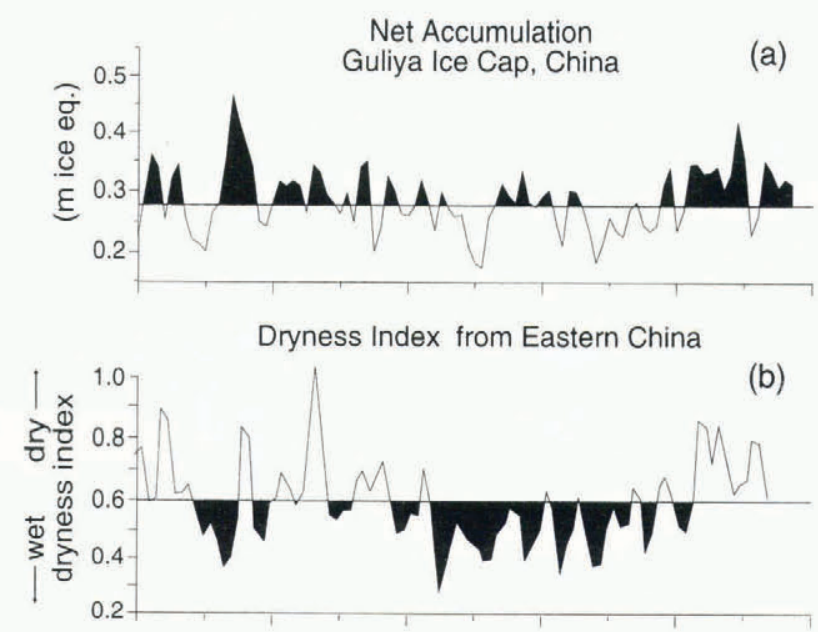

Net Accumulation
Dunde Ice Cap, China

(c)

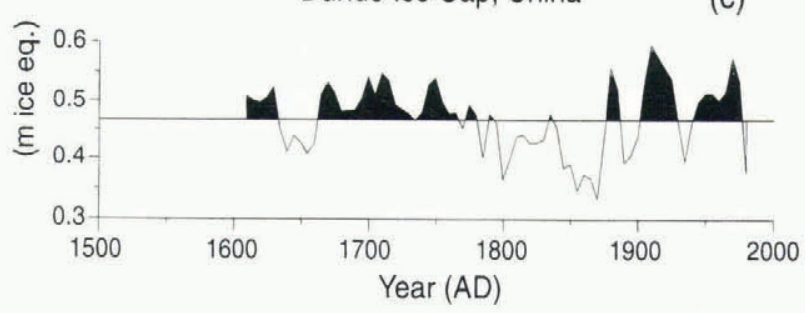

Fig. 7. Net accumulation since 1500 AD on (a) Guliva and (c) Dunde, with (b) the historical dryness index from eastern China from Zhang (1981). Drier conditions on Guliya tend to be associated with wetter conditions in eastern China. The ice-core annual accumulation data were treated identically to Zhang's dust indices; that is, 10 year running means were calculated and every fifth point was plotted. The dryness index $\left(I_{\mathrm{D}}\right)=2 \mathrm{D} / \mathrm{N}$ where $\mathrm{D}$ is the number of stations with a wetness/dryness grade of 4 or 5 and $N$ is the total number of stations considered. The "yearly charts" were used to compile the dala set of 100 stations in eastern China (see Wang and Zhang, 1992, p. 303).

Additional environmental information for the last 1000 years is available from the Guliya ice cap. Figure 9 presents the decadal averages of MPC, $\delta^{18} \mathrm{O}, \mathrm{NO}_{3}$, $\mathrm{SO}_{4}{ }^{2}$ and $\mathrm{Cl}$. The most negative $\delta^{18} \mathrm{O}$ values generally indicating lower temperatures) occur at the beginning of the current millennium. Thus, this record does not indicate the presence of the "Medieval Warm Epoch" (MWE) and supports the suggestion by Hughes and Diaz (1994) that the MWE was not global in extent. From 1300 to $1800 \mathrm{AD}$, contemporaneous with much of the "Little Ice Age" (I.IA), $\delta^{18} \mathrm{O}$ appears more enriched (suggesting warmer conditions) similar to the ice-core $\delta^{18} \mathrm{O}$ histories from sites in the Antarctic Peninsula (Aristarain and others, 1986; Peel, 1992; Thompson and others, 1995) and at Siple Station at the base of the Peninsula (Mosley-Thompson, 1992). The major isotopically warmer and cooler periods are not synchronous for Dunde and Guliya although both records show a persistence of warmer conditions since the 1940s (see Yao and Thompson, 1992; Lin and others, 1995).

There are two major periods of enhanced atmospheric dust concentrations, 1430-1550 and 1680-1900 AD, with shorter events (a few decades or less) centered on 1150 , 1300 and $1600 \mathrm{AD}$ as well as from 1950 to the present. 


\section{Net Accumulation ( $m$ ice eq.)}

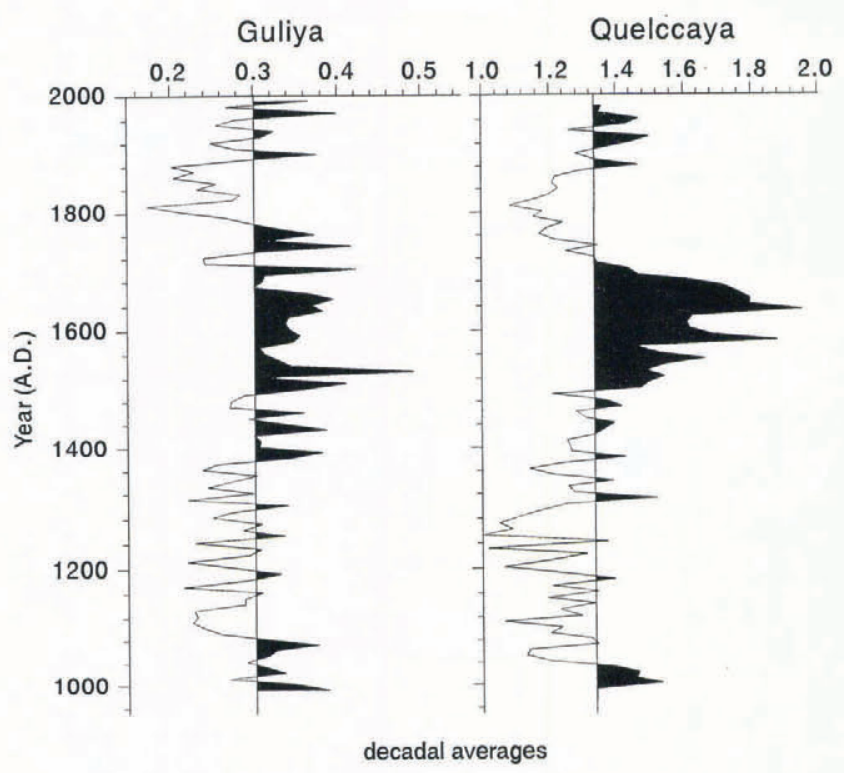

Fig. 8. The 1000 year record of net accumulation (as decadal averages) on Guliya reveals contemporaneous trends with net accumulation on the Quelccaya ice cap, Peru.

Most of the LIA period is characterized by elevated dust concentrations, consistent with the historical dust-fall records of Zhang (1984) and with ice-core dust records from the South Pole Mosley-Thompson and others, 1993) and Quelccaya ice cap (Thompson, 1992). The $\mathrm{NO}_{3}, \mathrm{SO}_{4}{ }^{2-}$ and $\mathrm{Cl}$ records show no long-term trends over the millennium, suggesting no anthropogenic contribution in the snow at this high-elevation site. The fluxes of $\mathrm{NO}_{3}, \mathrm{SO}_{4}{ }^{2-}$ and $\mathrm{Cl}^{-}$are consistently high from 1000 to $1300 \mathrm{AD}$ and remain consistently low thereafter to the present. All three anions exhibit brief (one or two decades long), contemporaneous concentration peaks around 1590 and $1710 \mathrm{AD}$. A second peak around 1620 occurs in $\mathrm{NO}_{3}{ }^{-}$and $\mathrm{Cl}$, but not in $\mathrm{SO}_{4}{ }^{2-}$. The major peaks in soluble anions occur when insoluble dust levels are low, suggesting that the soluble fraction of the aerosols has a different source from the insoluble fraction. In general, the more negative $\delta^{18} \mathrm{O}$ values from 1000 to $1300 \mathrm{AD}$ are associated with higher concentrations of $\mathrm{NO}_{3}{ }^{-}, \mathrm{SO}_{4}{ }^{2-}$ and $\mathrm{Cl}^{-}$and lower concentrations of insoluble dust.

\section{CONGLUSIONS}

Analyses of the ice cores from Guliya ice cap provide the first high-resolution, multi-proxy climate history from the far western Kunlun, China. This information should prove invaluable in the study of both regional and global climatic and environmental change on time-scales of decades to millennia. The $\delta^{18} \mathrm{O}$ records from the Dunde and Guliya ice caps in China and the Gregoriev ice cap reveal a significant enrichment in ${ }^{18} \mathrm{O}$ (indicating warming) over the past few decades (Thompson and others, 1993; Lin and others, 1995). Unlike the results from Dunde, the Guliya $\delta^{18} \mathrm{O}$ values for recent decades are not unprecedented (unique) in the last 1000 years. However, the recent warming over the Q-T Plateau is consistent with model results (e.g. Hansen and others, 1988) suggesting that the central region of the Asian continent may be one of the first places to exhibit an unambiguous signal of the anticipated "greenhouse warming" as it is far from the mitigating influences of oceans. More confident projections about future climate changes require better description and understanding of the sources of past natural climatic variance on the same time-scales (Bradley and Jones, 1993). Certainly, the

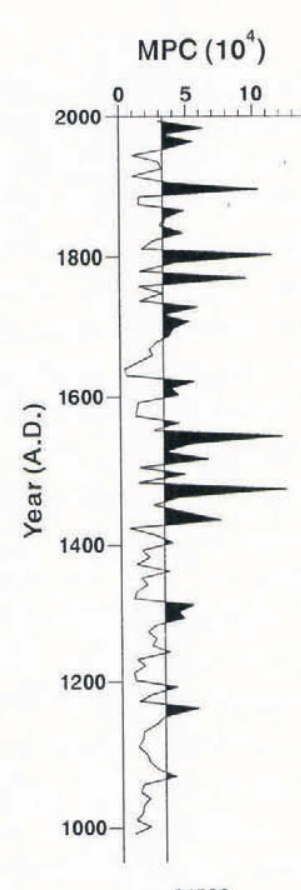

31500

1000-Year Guliya Ice Core Record

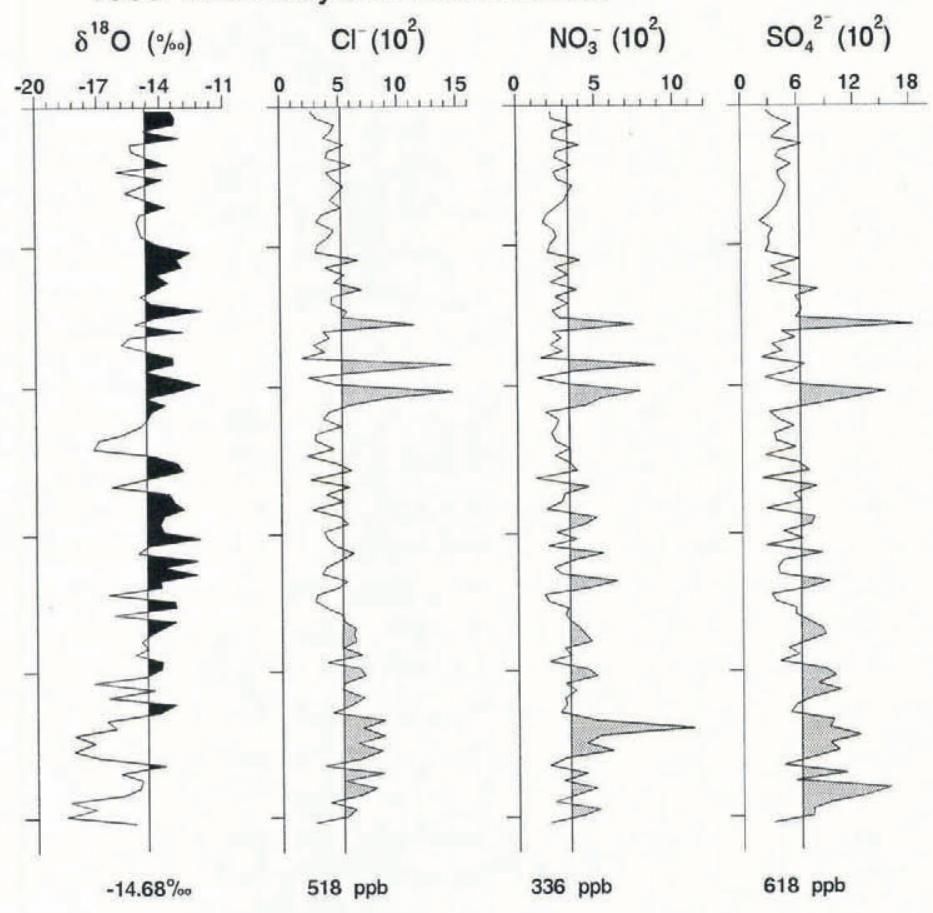

Fig. 9. Decadal averages of MPC (microparticle concentrations (diameters $\geq 2.0 \mu \mathrm{m})$ ) per milliliter sample, $\delta^{18} \mathrm{O}$, and concentrations of $\mathrm{CT}, \mathrm{NO}_{3}$ and $\mathrm{SO}_{4}{ }^{2}$ in ppb, along with their respective averages for the last 1000 years on the Guliya ice cap. Averages for each profile are shown. 
potential impact of global warming on the strength of the monsoon system could be significant and warrants investigation (Meehl and Washington, 1993).

The $308.6 \mathrm{~m}$ core from Guliya is the longest ice core retrieved from an elevation greater than $4000 \mathrm{~m}$. Based upon (1) our preliminary examination of air bubbles and crystal sizes, (2) subsequent analyses of selected sections over the complete length of the core for $\delta^{18} \mathrm{O}$ and dust concentration, and (3) a preliminary time-scale calculation based on visible dust-layer thicknesses, it appears that the Guliya core may contain ice deposited over the last 400000 years. If so, the experience from the Greenland GISP2 core Grootes and others, 1993) dictates extremely careful study and cautious interpretation of the lower part of the core, as the potential for disturbance is high in the lower part of the core. Thus, understanding the records of the last millennium presented in this paper provides a starting-point for accurate interpretation of the much longer histories preserved in the lower $200 \mathrm{~m}$ of the Guliya deep core.

\section{ACKNOWLEDGEMENTS}

This research was supported by the U.S. National Science Foundation's Office of Climate Dynamics and the Division of Polar Programs (ATM-8519794, ATM89116635, DPP-9014931), the National Geographical Society (3323-86, 4309-90 and 4522-91), The Ohio State University and the National Natural Science Foundation of China. The efforts of all American, Chinese, Russian and Peruvian field participants are gratefully acknowledged. We thank the Polar Ice Core Office and B. Koci, in particular, for drilling the deep ice cores. Dr G. Larson of Michigan State University conducted the tritium analyses, and the illustrations were prepared by J. Nagy. This is contribution No. 914 of the Byrd Polar Research Center.

\section{REFERENCES}

Ageta, Y. and 7 others. 1991. Glaciological studies on Qingzang plateau, 1989. Part 2: Glaciology and geomorphology. Bull. Glacier Res. 9, 27-32.

Aristarain, A.J., J. Jouzel and M. Pourchet. 1986. Past Antarctic Peninsula climate $(1850-1980)$ deduced from an ice core isotope record. Climatic Change, 8 1), 6989.

Barnett, T. P., L. Dümenil, U. Schlese and E. Roeckner. 1988. The effect of Eurasian snow cover on global climate. Science, 239 4839), 504-507.

Barry, R. G. and R. Chorley. 1992. Atmosphere, weather and climate. Sixth edition. London, etc.. Routledge.

Bradley, R.S. and P.D. Jones. 1993. "Little Ice Age" summer temperature variations: their nature and relevance to recent global warming trends. Holocene, 3 4), 367-376.

Dai, J., L. G. Thompson and E. Mosley-Thompson. 1995. A 485 year record of atmospheric chloride, nitrate and sulfate: results of chemical analysis of ice cores from Dyer Plateau, Antaretic Peninsula, Ann. Glaciol., 21 (see paper in this volume).

Dey. B., S. N. Kathuria and O.B. Kumar. 1985. Himalayan summet snow cover and withdrawal of the Indian summer monsoon. 7 . Climate Appl. Meteorol., 24 8), 865868.
Domrös, M. and P. Gongbing. 1988. The climate of China. New York, etc.. Springer-Verlag.

Grootes, P. M., M. Stuiver, J. W. C. White, S. Johnsen and J. Jouzel. 1993. Comparison of oxygen isotope records from the GISP2 and GRIP Greenland ice cores. Nalure, 366 645.5 , 552-554.

Hansen, J. and S. Lebedeff. 1987. Global trends of measured surface air temperature.J. Geophys. Res., 92 D11), 13,345-13,372.

Hughes, M.K. and H.F. Diaz. 1994. Was there a "Medieval Warm Period", and if so, where and when? Climatic Change, 25, 109142.

Lin, P. -N., L. G. Thompson, M. E. Davis and E. Mosley-Thompson. 1995. 1000 years of climatic change in China: ice-core $\delta^{i 8} \mathrm{O}$ cvidence. Ann. Glaciol., 21 see paper in this volume).

Meehl. G. A. and W. N. Washington. 1993. South Asian summer monsoon variability in a model with doubled atmospheric carbon dioxide concentration. Science, 260, 1101-1104.

Mosley-Thompson, E. 1992. Paleoenvironmental conditions in Antarctica since A.D. 1500: ice core evidence. In Bradley, R. S. and P. D. Jones, eds. Climate simee A.D. 1500. London and New York, Routledge, 572-591.

Mosley-Thompson, E.. L. G. Thompson. J. Dai, M. Davis and P. N. Lin. 1993. Climate of the last 500 years: high resolution ice core records. Qual. Sci. Ret., 126 , 419-430.

Namias, J. 1963. Interactions of circulation and weather between hemispheres. Mon. Weather Rer., 91, 482-486.

Peel, D. A. 1992. Ice core evidence from the Antarctic Peninsula region. In Bradley, R. S. and P. D. Jones, eds. Climate since A.D. 1500. London and New York, Routledge, 549571.

Ramage, C.S. 1971. Monsoon meteorology. New York, etc., Academic Press.

Rasmusson, E. M. and T. H. Carpenter, 1983. The relationship between eastern equatorial Pacific Sea surface temperatures and rainfall over India and Sri Lanka. Mon. Weather Rez., 111, 517-528.

Shi, Y. and J. Wang. 1981. The fluctuations of climate, glaciers and sea level since late Pleistocene in China. International Association of Hydrological Sciences Publication 131 Symposium at Canberra 1979 - Sea Level, Lee and Climatic Change), 281-293.

Thompson. L. G. 1992. Ice core evidence from Peru and China. In Bradley, R.S. and P. D. Jones, eds. Climate since A.D. 1500. London and New York, Routledge, 517-548.

Thompson L. G., E. Mosley-Thompson, P. M. Grootes, M. Pourchet and S. Hastenrath. 1984. Tropical glaciers: potential for ice core paleoclimatic reconstructions. J. Geophys. Res., 89 D3), 4638-4646.

Thompson, L. G., E. Mosley-Thompson. J. F. Bolzan and B. R. Koci. 1985. A 1500-year record of tropical precipitation in ice cores from the Quelecaya ice cap, Peru. Science, 229 4717). 971-973.

Thompson, L. G., E. Mosley-Thompson, W. Dansgaard and P. M. Grootes, 1986. The Little Ice Age as recorded in the stratigraphy of the tropical Quelccaya ice cap. Science, 234 4774), 361-364.

Thompson, L. G.. M. E. Davis, E. Mosley-Thompson and K-b. Liu. 1988. Pre-Incan agricultural activity recorded in dust layers in two tropical ice cores. Nature, 336 6201), 763-765.

Thompson, L. G, and 9 others. 1989. Holocene-Late Pleistocene climatic ice core records from Qinghai-Tibetan Plateau. Science, 2464929 . 474477.

Thompson, L.G. and 6 others. 1993. "Recent warming": ice core evidence from tropical ice cores with emphasis on central Asia. Global and Planetary Change, 7 1-3), $145-156$.

Thompson, L. G. and 7 others. 1995. Climate since AD 1510 on Dver Plateau, Antarctica Peninsula: evidence for recent climate change, Ann. Glaciol., 20, $420-426$.

Wang, P. K. and D. Zhang. 1992. Recent studies of the reconstruction of east Asian monsoon climate in the past using historical literature of China. J. Meteorol. Soc. Jpm, 70 1), 293-146.

Yao Tandong and L.G. Thompson. 1992. Trends and features of climatic changes in the past 5000 years recorded by the Dunde ice core. Ann. Glaciol., 16, $21-24$.

Zhang, D. 1984. Synoptic-climatic studies of dust fall in China since historic times. Sci. Sin., Ser. B, 27, $825-836$.

Zhang, J. and T.J. Crowley. 1989. Historical climate records in China and reconstruction of past climates. 7 . Climate, 2 8, 833-849.

Zhang, X. 1981. The analysis of the index of drvness in the last 500 vears in eastern China. In Proceedings of the Conference on Fluctuations of the Climate. 1978. Beijing, Science Press, 46-51. [In Chinese.] 